\title{
ANTIGENiC SUbSTANCE OF PASTEURella PEstis CONCERNING HEMAGGLUTINATION
}

\author{
Hideo FUKUMI, HaYaTo KANEKO AND Eiko SAYAMA
}

The National Institute of Health Tokyo, Japan

(Received: October 8th, 1954)

\section{INTRODUCTION}

Amies(1) obtained good results for hemagglutination reaction with a partly purified preparation of the envelope substance of Pasteurella pestis,* while Chen(2) stated that the antigen of this organism responsible for the hemagglutination reaction is of carbohydrate nature and the protein antigen which Baker et al considered to be derived from the envelope and to produce the protective antibody, is unable to sensitize normal erythrocytes. However, according to Landy and Trapani(3), the purified envelope protein of Pasteurella pestis is capable of sensitizing the erythrocytes for agglutination reaction by its antibody, if they are treated with tannic acid. This is also the case for the purified toxin of Pasteurella pestis.(4)(5)

The present authors extracted a substance of carbohydrate nature from Pasteurella pestis by a fairly simple procedure which is able to sensitize erythrocytes for hemagglutination reaction. This paper is dedicated to the description of this finding.

\section{EXPERIMENTALS}

Method for estimating hemagglutinating titer of sera by sensitized erythrocytes:

In routine procedures, supernatant of heated bacterial suspension was employed for sensitization of erythrocytes. An usual agar slant culture of Pasteurella pestis (cultivated for 48 hours usually) was suspended in about $5 \mathrm{ml}$ of physiological saline, heated in a boiling water-bath for 30 minutes and then centrifuged at 3,000 RPM for 30 minutes. The supernatant was added to equal valume of $10 \%$ suspension of sheep erythrocytes in physiological saline and left standing at $37^{\circ} \mathrm{C}$ for one hour. The erythrocyte suspension thus sensitized was then diluted up to $0.25 \%$ and utilized for hemagglutination.

Filtration of serum for hemagglutination was run by using the antigen obtained above as follows:

\begin{tabular}{lccccccc} 
Serum dilution & 10 & $10 \times 2$ & $10 \times 2^{2}$ & $10 \times 2^{3}$ & $10 \times 2^{4}$ & $10 \times 2^{5}$ & $10 \times 2^{6}$ \\
Amount of serum diluted & 0.5 & 0.5 & 0.5 & 0.5 & 0.5 & 0.5 & $0.5(\mathrm{ml})$ \\
$\begin{array}{l}\text { Amount of sensitized ery- } \\
\text { throcyte suspension }\end{array}$ & 0.5 & 0.5 & 0.5 & 0.5 & 0.5 & 0.5 & $0.5(\mathrm{ml})$ \\
\hline Final serum dilution & $10 \times 2$ & $10 \times 2^{2}$ & $10 \times 2^{3}$ & $10 \times 2^{4}$ & $10 \times 2^{5}$ & $10 \times 2^{6}$ & $10 \times 2^{7}$
\end{tabular}

Standing at room temperature.

Reading was made by sedimenting bottom figures. 
Serum employed:

The serum (Kuma 3) of a rabbit immunized with killed suspension of Pasteurella pestis (strain Kuma) was employed throughout. The hemagglutination titer was estimated by means of the method mentioned above as follows:

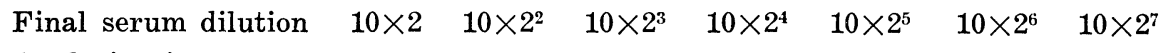

Agglutination

Several other sera from rabbits immunized in the same way were also estimated for their hemagglutinating titer, but there was no one whose hemagglutinating titer was high enough for our use.

Measurement of the amount of sensitizing substance by means of hemagglutination inhibition reaction:

Hemagglutination of sensitized erythrocyte suspension by antibody is inhibited if antibody is mixed with the sensitizing substance before addition of sensitized erythrocyte suspension. This phenomenon can be utilized for measurement of the amount of the sensitizing substance. The procedure employed was as follows:

\begin{tabular}{|c|c|c|c|c|c|c|c|c|}
\hline $\begin{array}{l}\text { Dilution of sensitizing sub- } \\
\text { stance }\end{array}$ & $2^{0}$ & $2^{1}$ & $2^{2}$ & $2^{3}$ & $2^{4}$ & $2^{5}$ & $2^{6}$ & $2^{7}$ \\
\hline Amount of the above & 0.25 & 0.25 & 0.25 & 0.25 & 0.25 & 0.25 & 0.25 & $0.25(\mathrm{ml})$ \\
\hline $\begin{array}{l}\text { Amount of serum (Kuma } 3 \\
\text { ten times diluted) }\end{array}$ & 0.25 & 0.25 & 0.25 & 0.25 & 0.25 & 0.25 & 0.25 & $0.25(\mathrm{ml})$ \\
\hline \multicolumn{9}{|c|}{ Incubation at $37^{\circ} \mathrm{C}$ for 30 minutes, then added with } \\
\hline $\begin{array}{l}\text { Sensitized erythrocyte sus- } \\
\text { pension }\end{array}$ & 0.5 & 0.5 & 0.5 & 0.5 & 0.5 & 0.5 & 0.5 & $0.5(\mathrm{ml})$ \\
\hline \multicolumn{9}{|c|}{ Standing at room temperature. } \\
\hline $\begin{array}{l}\text { Final dilutions of sensitiz- } \\
\text { ing substance }\end{array}$ & $2^{2}$ & $2^{3}$ & $2^{4}$ & $2^{5}$ & $2^{6}$ & $2^{7}$ & $2^{8}$ & $2^{9}$ \\
\hline
\end{tabular}

Extraction of the sensitizing substance from bacterial cells:

A bacterial cell suspension in physiological saline of Pasteurella pestis (strain Kuma) was divided into two portions. One portion was centrifuged down after enough shaking, while the other portion was heated in a boiling water bath for 30 minutes and then centrifuged down. The supernatants of the both portions were employed for sensitization of erythrocyte as described above. The result of the titrations of the serum Kuma 3 using the sensitized erythrocyte suspensions thus obtained is shown in Table 1.

As shown in this table, the titer obtain with the supernatant of unheated cells was somewhat lower than that obtained with the supernatant of heated cells. It may be assumed that more amount of the sensitizing substance is liberated from cells by heating, or that there may be some unknown substance

* According to Landy and Trapani(3), Amies could not repeat his early findings, when he was able to use a pure antigen free from carbohydrate. 
Table 1. Comparison of the activity of the supernatants of heated and unheated cells of Pasteurella pestis

\begin{tabular}{c|c|c|c|c|c}
\hline $\begin{array}{r}\text { Serum dilution } \\
\text { (Kuma 3) }\end{array}$ & $10 \times 2$ & $10 \times 2^{2}$ & $10 \times 2^{3}$ & $10 \times 2^{4}$ & $10 \times 2^{5}$ \\
$\begin{array}{c}\text { Sensitiz- } \\
\text { ing antigen }\end{array}$ & + & + & - & - & - \\
\hline $\begin{array}{c}\text { Supernatant of } \\
\text { unheated cells } \\
\begin{array}{c}\text { Supernatant of } \\
\text { heated cells }\end{array}\end{array}$ & + & + & + & + & -
\end{tabular}

inhibiting the hemagglutination which is inactivated by heating. So, the influence of heating upon the extraction of the sensitizing substance from cells was next examined.

A bacterial suspension of Pasteurella pestis (strain Kuma) in physiological saline was divided into seven portions. The first portion was centrifuged down after enough shaking. The remaining six portions were each heated at $50^{\circ} \mathrm{C}$, $60^{\circ} \mathrm{C}, 70^{\circ} \mathrm{C}, 80^{\circ} \mathrm{C}, 90^{\circ} \mathrm{C}$, and $100^{\circ} \mathrm{C}$. respectively for 30 minutes, and then centrifuged down at 3,000 RPM for 30 minutes. The amount of the sensitizing substance in each supernatant thus obtained was titrated by the hemagglutination inhibition reaction described above as shown in Table 2.

Table 2. Influence of temperature upon the extraction of the erythrocyte-sensitizing substance from cells

\begin{tabular}{|c|c|c|c|c|c|c|}
\hline $\begin{array}{l}\begin{array}{c}\text { Dilution of } \\
\text { supernatant }\end{array} \\
\text { Tempera- } \\
\text { ture applied }\end{array}$ & $2^{2}$ & $2^{3}$ & $2^{4}$ & $2^{5}$ & $2^{6}$ & $2^{7}$ \\
\hline unheated & - & - & - & + & + & + \\
\hline heated at $50^{\circ} \mathrm{C}$ & - & - & - & + & + & + \\
\hline $60^{\circ} \mathrm{C}$ & - & - & - & + & + & + \\
\hline " $\quad 70^{\circ} \mathrm{C}$ & - & - & - & \pm & + & + \\
\hline$\Rightarrow \quad 80^{\circ} \mathrm{C}$ & - & - & - & - & + & + \\
\hline$" \quad 90^{\circ} \mathrm{C}$ & - & - & - & - & + & + \\
\hline$\Rightarrow \quad 100^{\circ} \mathrm{C}$ & - & - & - & - & + & + \\
\hline
\end{tabular}

Thus, it has become clear that heating can liberate more amount of the sensitizing substance from cells of Pasteurella pestis, and further that this substance is not inactivated by heating at $100^{\circ} \mathrm{C}$ for 30 minutes. This is the reason why we employed the heating in a boiling water bath for extracting the sensitizing substance for routine procedure.

The next experiment was made for determining whether every strain of Pasteurella pestis, either virulent or avirulent, contains enough amount of the sensitizing substance in the cell. The strains employed for this experiment were as follows: 
Kuma

Yoko Virulent strains

EV avirulent strain obtained from Dr. L. Otten

$\mathrm{M}^{2}-40 \quad$ avirulent strain received from Dr. T. Kasuga

These strains were each inoculated on a usual agar slant and the culture was suspended in $5 \mathrm{ml}$ of physiological saline. The solution of the sensitizing substance was thus obtained from each of the above strains by the usual procedure. The result of the titration for the sensitizing substance of each preparation by means of hemagglutination inhibition reaction is shown in Table 3.

Table 3. Comparison of various strains for the content of erythrocyte-sensitizing substance

\begin{tabular}{l|c|c|c|c|c|c|c}
\hline $\begin{array}{c}\text { Dilution of pre- } \\
\text { paration }\end{array}$ & $2^{2}$ & $2^{3}$ & $2^{4}$ & $2^{5}$ & $2^{6}$ & $2^{7}$ & $2^{8}$ \\
\hline Kuma & - & - & - & \pm & + & + & + \\
Yoko & - & - & + & + & + & + & + \\
FV & - & - & - & - & \pm & + & + \\
$\mathbf{M}^{2}-40$ & - & - & - & - & \pm & + & +
\end{tabular}

All of them contain the erythrocyte-sensitizing substance in their cells. Purification of the erythrocyte-sensitizing substance by isoelectric precipitation:

A solution of the erythrocyte-sensitizing substance obtained by heat-extraction from cells of Pasteurella pestis (Kuma strain) was adjusted to $\mathrm{pH}$ 4.0 by addition of hydrochloric acid and the resulting precipitate was separated from the supernatant by centrifugation. The precipitate was resuspended in phosphate buffer of $\mathrm{pH}$ 7.0. The supernatant was again adjusted to $\mathrm{pH}$ 7.0. Hemagglutination inhibition activities of these products were titrated as shown in Table 4.

Table 4. Acid-solubility of the erythrocyte-sensitizing substance

\begin{tabular}{l|c|c|c|c|c|c}
\hline $\begin{array}{r}\text { Dilution of pre- } \\
\text { paration }\end{array}$ & $2^{2}$ & $2^{3}$ & $2^{4}$ & $2^{5}$ & $2^{6}$ & $2^{7}$ \\
Treatment & - & - & - & \pm & + & + \\
$\begin{array}{l}\text { Original supernatant } \\
\text { of heated cells } \\
\begin{array}{l}\text { Supernatant of pH } \\
4.0 \text { treatment }\end{array}\end{array}$ & - & - & - & \pm & + & + \\
Precipitate at pH 4.0 & + & + & + & + & + & +
\end{tabular}

From this experiment, it is evidenced that the precipitate at $\mathrm{pH} 4.0$ contains no sensitizing substance, and this remains intact in the supernatant.

Purification of the erythrocyte-sensitizing substande by salting out with ammonium sulfate:

Precipitate was obtained from supernatant of heated cells of Pasteurella 
pestis (strain Kuma) by addition of ammonium sulfate at $25 \%$ saturation. The precipitate was resuspended in physiological saline and used for sensitization of erythrocytes. The erythrocyte suspension thus sensitized was also agglutinated by the plague-immune serum (Kuma 3). Thus, two kinds of sensitized erythrocytes were available: (1) erythrocytes sensitized by the supernatant of heated plague cells and (2) erythrocytes sensitized by the product of salting out with ammonium sulfate at $25 \%$ saturation.

Aceton-precipitate was prepared by addition of aceton to a lot of supernatant of heated plague cells in the proportion of 3 volumes of aceton to 1 volume of the supernatant. Further, a preparation (33\%-Amm-Aceton-precipitate) was made by addition of aceton to a precipitated preparation of salting out by ammonium sulfate at $33 \%$ saturation. These two preparations and the mere supernatant, from which they had been prepared, were estimated for their inhibiting titer for the hemagglutination reaction of the both kinds of sensitized erythrocytes made above as shown in Table 5. It indicates that the inhibition was observed in almost the same titer in each preparation for both kinds of the sensitized erythrocytes.

Table 5. Precipitation of the erythrocyte-sensitizing substance with ammonium sulfate and aceton (1)

\begin{tabular}{|c|c|c|c|c|c|c|c|c|c|}
\hline \multirow{2}{*}{$\begin{array}{l}\text { Inhibiting } \\
\text { substance }\end{array}$} & \multirow{2}{*}{$\begin{array}{l}\text { Sensitizing } \\
\text { substance }\end{array}$} & \multicolumn{8}{|c|}{ Dilution of inhibiting substance } \\
\hline & & $2^{2}$ & $2^{3}$ & $2^{4}$ & $2^{5}$ & $2^{6}$ & $2^{7}$ & $2^{8}$ & $2^{9}$ \\
\hline \multirow{2}{*}{$\begin{array}{l}\text { Supernatant } \\
\text { of heated } \\
\text { cells }\end{array}$} & $\int \begin{array}{ll}\text { Sup. } & \begin{array}{l}\text { heated } \\
\text { cells }\end{array}\end{array}$ & - & - & - & - & - & - & + & + \\
\hline & $\left\{\begin{array}{l}\text { Precipitate with } \\
25 \% \text { saturation of } \\
\text { amm. sulf. }\end{array}\right.$ & - & - & - & - & - & - & \pm & + \\
\hline \multirow{2}{*}{$\begin{array}{c}\text { Precipitate } \\
\text { with } \\
\text { aceton }\end{array}$} & $\left\{\begin{array}{l}\text { Sup. } \\
\text { cells }\end{array}\right.$ & - & - & - & - & - & - & + & + \\
\hline & $\left\{\begin{array}{l}\text { Precipitate with } \\
25 \% \text { saturation of } \\
\text { amm. sulf. }\end{array}\right.$ & - & - & - & - & - & - & \pm & + \\
\hline \multirow{2}{*}{$\begin{array}{l}\text { Precipitate } \\
\text { with aceton } \\
\text { after precipi- } \\
\text { tation with } \\
33 \% \text { satura- } \\
\text { tion of amm. } \\
\text { sulf. }\end{array}$} & $\mid \begin{array}{ll}\text { Sup. } & \begin{array}{l}\text { heated } \\
\text { cells }\end{array}\end{array}$ & - & - & - & - & - & \pm & + & + \\
\hline & $\begin{array}{l}\text { Precipitate with } \\
25 \% \text { saturation of } \\
\text { amm. sulf. }\end{array}$ & - & - & - & - & - & - & + & + \\
\hline
\end{tabular}

The next experiment was run in the following manner. Three preparations were made as follows:

1) A supernatant was made from heated cells of Pasteurella pestis (Kuma) in the usual way, (Original)

2) This supernatant was precipitated by half saturation of ammonium sulfate and the precipitate was resuspended in $1 / 5$ volume of physiological saline (50\%-Amm. precipitate, five times concentrated)

3) The supernatant of the half-saturation of Ammonium sulfate was 
precipitated by 3 volume of aceton after dialyzation and the resulting precipitate was resuspended in $1 / 5$ volume of physiological saline (aceton-precipitate, five times concentrated).

The inhibition titer of these preparation was estimated for the hemagglutination reaction with erythrocytes sensitized by the heat extracted substances as shown in Table 6. The inhibition was also confirmed in this case.

Table 6. Precipitation of the erythrocyte-sensitizing substance with ammonium sulfate and aceton (2)

\begin{tabular}{|c|c|c|c|c|c|c|c|c|c|}
\hline \multirow{2}{*}{ Inhibiting substance } & \multirow{2}{*}{$\begin{array}{l}\text { Sensiti- } \\
\text { zation } \\
\text { with }\end{array}$} & \multicolumn{8}{|c|}{ Dilution of inhibiting substance } \\
\hline & & $2^{2}$ & $2^{3}$ & $2^{4}$ & $2^{5}$ & $2^{6}$ & $2^{7}$ & $2^{8}$ & $2^{9}$ \\
\hline $\begin{array}{l}\text { Supernatant of heated } \\
\text { cells }\end{array}$ & \multirow{3}{*}{$\begin{array}{l}\text { Superna- } \\
\text { tant of } \\
\text { heated } \\
\text { cells }\end{array}$} & 一 & 一 & \pm & + & + & + & + & + \\
\hline $\begin{array}{l}\text { Precipitate with } 50 \% \\
\text { Amm. sulf. satura- } \\
\text { tion (5 times con- } \\
\text { centrated) }\end{array}$ & & 一 & 一 & - & \pm & + & + & + & + \\
\hline $\begin{array}{l}\text { Aceton-precipitate of } \\
\text { the supernatant of } \\
\text { the above precipi- } \\
\text { tation ( } 5 \text { times con- } \\
\text { centrated) }\end{array}$ & & 一 & 一 & - & \pm & + & + & + & + \\
\hline
\end{tabular}

Finally, three preparations of sensitized erythrocyte suspension:

1) Erythrocytes sensitized by a supernatant of heated plagues cells.

2) Erythrocytes sensitized by a $33 \% \mathrm{Amm}$. and aceton precipitated preparation.

3) Erythrocytes sensitized by $25 \% \mathrm{Amm}$. and precipitated preparation.

A supernatant preparation from heated plague organisms was estimated for its inhibision titer to the hemagglutination reaction of the three kinds of sensitized erythrocytes. The result is shown in Table 7 , indicating that the inhibision took place in all these cases, too.

Table 7. Precipitation of the erythrocyte-sensitizing substance with ammonium sulfate and aceton (3)

\begin{tabular}{|c|c|c|c|c|c|c|c|c|c|}
\hline \multirow{2}{*}{$\begin{array}{c}\text { Inhibiting } \\
\text { substance }\end{array}$} & \multirow{2}{*}{ Sensitization with } & \multicolumn{8}{|c|}{ Dilution of inhibiting substance } \\
\hline & & $2^{2}$ & $2^{3}$ & $2^{4}$ & $2^{5}$ & $2^{6}$ & $2^{7}$ & $2^{8}$ & $2^{9}$ \\
\hline \multirow{3}{*}{$\begin{array}{l}\text { Superna- } \\
\text { tant of } \\
\text { heated } \\
\text { cells }\end{array}$} & $\begin{array}{l}\text { Supernatant of heat- } \\
\text { ed cells }\end{array}$ & - & - & - & - & \pm & + & + & + \\
\hline & $\begin{array}{l}\text { Aceton-precipitate of } \\
\text { the precipitate with } \\
33 \% \text { amm. sulf. sa- } \\
\text { turation }\end{array}$ & - & - & - & - & - & + & + & + \\
\hline & $\begin{array}{l}\text { Precipitate with } 25 \% \\
\text { amm. sulf. satura- } \\
\text { tion }\end{array}$ & - & - & - & - & - & + & + & + \\
\hline
\end{tabular}


The experimental results mentioned above are considered, as a whole, to indicate that the erythrocyte-sensitizing substance is precipitated either by aceton or by $25-50 \%$ saturated ammonium sulfate.

Baker, et al(6) (7) identified at least three soluble antigenic components from a culture supernatant fluid or from aceton killed plague organisms: (1) a carbohydrate protein complex (Fraction IA); (2) a carbohydrate-free protein (Fraction IB); (3) a toxic fraction (Fraction II), and Chen (2) stated that the purified preparations of IA and IB were unable to sensitize erythrocytes or to inhibit the hemagglutination reaction. These preparations of IA and IB were obtained by salting out with ammonium sulfate at $25-33 \%$ saturation, and according to Chen, the erythrocyte-sensitizing substance remained in the supernatant of the salting-out. This may be discrepant with our result of ammonium sulfate precipitation of the erythrocyte-sentizing substance described above, so we ourselves tried to obtain the fractions IA and IB by following the method described by Baker et al ${ }^{(6)}$. Our preparations of IA and IB had some erythrocyte-sensitizing activity but their titers were $1 / 2 \sim 1 / 4$ of $25 \%$ ammonium sulfate saturation residue.

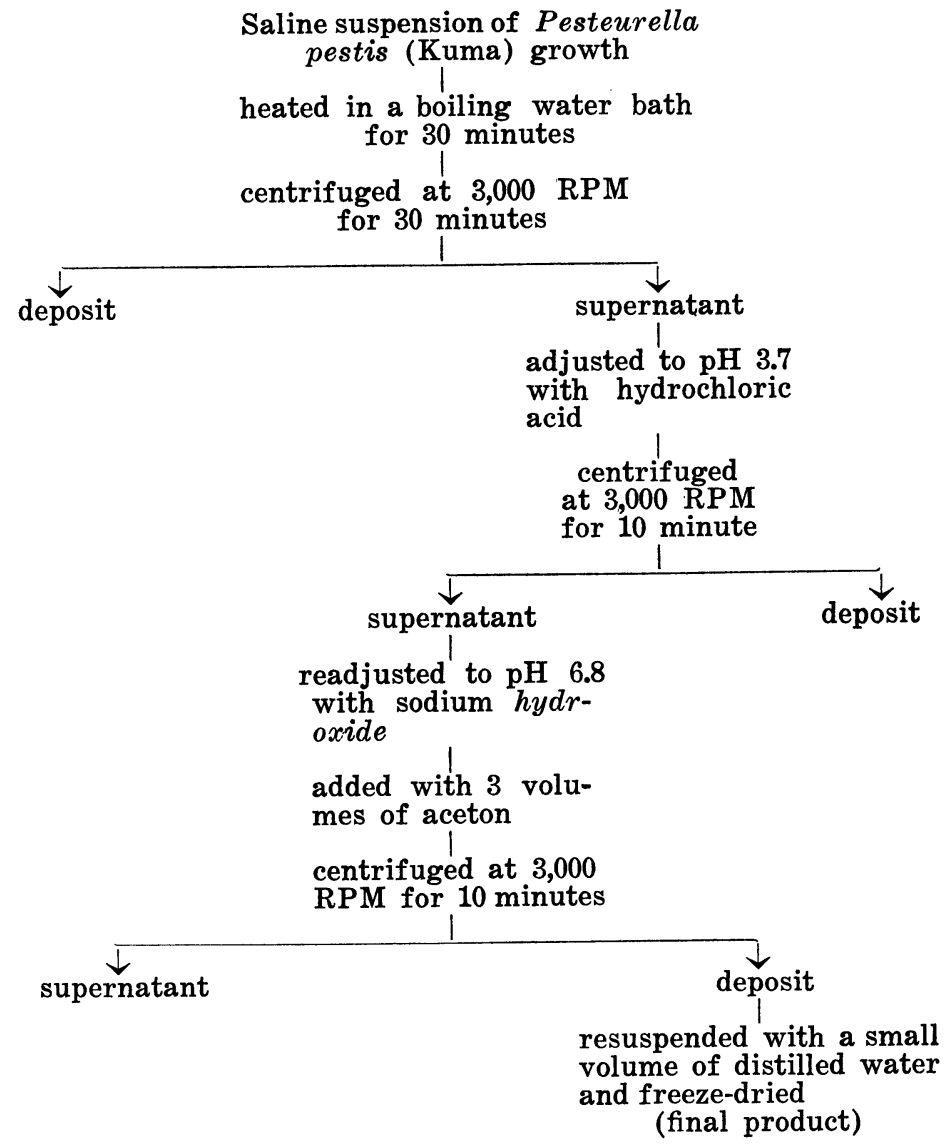

Diagram 1 
It seems that the salting-out by ammonium sulfate always precipitates the erythrocyte-sensitizing substance with the proteinous antigen or antigens of Pasteurelle pestis from the culture supernatant. At any rate, the salting-out procedure with ammonium sulfate does not seem to be adequate for purification of the erythrocyte-sensitizing substance.

Partially purified preparation of the erythrocyte-sensitizing substance of Pasteurella pestis:

From the results of the preliminary experiments described above, we employed isoelectric separation and aceton precipitation to try to purify partially the erythrocyte-sensitizing substance of Pasteurella pestis. The preparation procedure is shown in Diagram 1, starting with a saline suspension of 48 hours' growth of Pasteurella pestis (strain Kuma).

The chemical properties and the hemagglutination inhibition titer of the final product were estimated as follows:

$\mathrm{N}$ :

Molisch:

Ninhydrine:

Millon:

Burret:

\section{Hemagglutination}

inhibition titer:

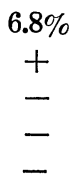

$2^{7} \times 10^{2}$

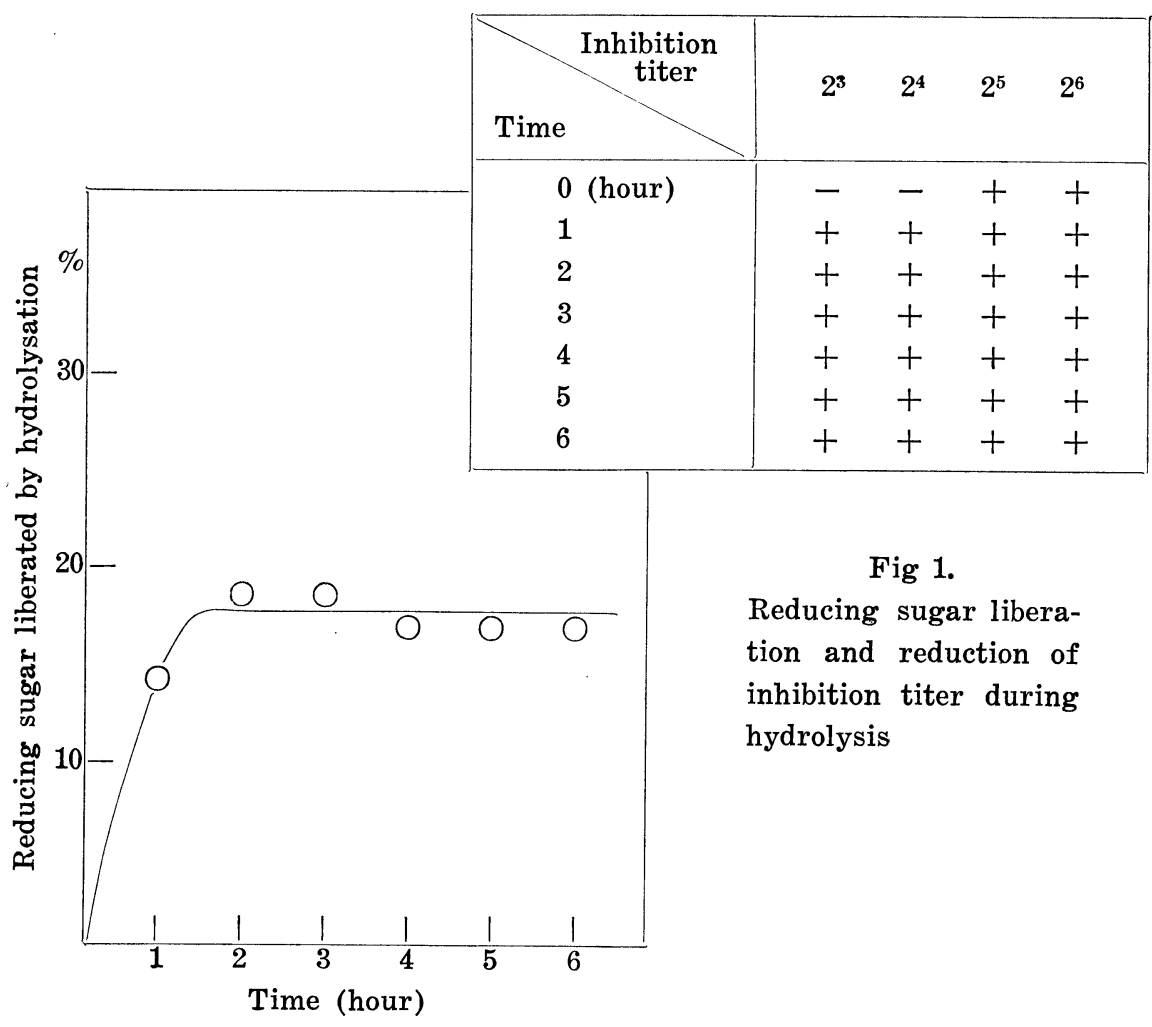


From these date the preparation thus obtained is probable to be of carbohydrate nature, though its nitrogen content is semewhat higher than the usual polysaccharides.

An ammount of $30.6 \mathrm{mg}$ of the above product was redissolved in $30 \mathrm{ml}$ of $1 \mathrm{~N} \mathrm{HCl}$ and heated in a boiling water bath for hydrolyzation. The reducing sugar liberated by the hydrolyzation and the hemagglutination-inhibition titer of the hydrolysate were estimated from time to time during the process of hydrolyzation. The result is shown in Fig. 1. The reducing sugar was estimated by means of Hagedorn and Jensen's procedure. Only above 18\% of our product was constituted of the reducing sugar, which was liberated by hydrolyzation in $1 \mathrm{~N} \mathrm{HCl}$. The hydrolyzation was completed within 2 hours and about $80 \%$ of the total reducing sugar was liberated in the first one hour. In parallel with this finding the inhibition titer was also lowered more than $75 \%$.

As seen obviously, our preparation of the erythrocyte-sensitizing substance of Pasteurelle pestis is never considered to be a pure product, but it contains this substance in a certain amount, whose activity is destroyed with the liberation of reducing sugar by hydrolyzation in acid medium. From this finding, its carbohydrate nature is highly probable.

\section{SUMMARY}

The erythrocyte-sensitizing substance of Pasteurella pestis is a certain kind of polysaccharide which is fairly heat-stable.

\section{REFERENCES}

(1) Amies, C.R.: The envelope substance of Pasteurella pestis. Brit. J. exp. Path., 32, 259-273, 1953.

(2) Chen, T.H.: Studies on immunization against plague. IV. The method of the hemagglutination test and some observations on the antigen. J. Imm., 69, 587-596, 1952.

(3) Landy, M., and Trapani, R.J.: A hemagglutination test for plague antibody with purified capsular antigen of Pasteurelle pestis. Am. J. Hyg., 59, 150-156, 1954.

(4) Aji, S. J., Reedal, J., Durrum, E. L., and Warren, J.: Studies on plague: I. Purification and properties of the endotoxin of Pasteurella pestis. Feder. Proc, 13, 4851954.

(5) Warren, J., Walz, U.L., Reedal, J., and Ajl, S.J.: Studies on plague: II. Serologic investigation of Pasteurella pestis endotoxin and specific rabbit antitoxin, Feder. Proc., 13, 517, 1954.

(6) Baker, E.E., Sommer, H., Foster, L.E., Meyer, E., and Meyer, K.F.: Antigenic structure of Pasteurella pestis and the isolation of a erystalline antigen, Proc. Soc. Exp. Biol. Med., 64, 139-142, 1947.

(7) Baker, E.E., Sommer, H., Foster, L.E., Meyer, E., and Meyer, K.F.: Studies on immunization against plague, I. The isolation and characterization of the soluble antigen of Pasteurella, J. Imm., 68, 131-145, 1952. 